
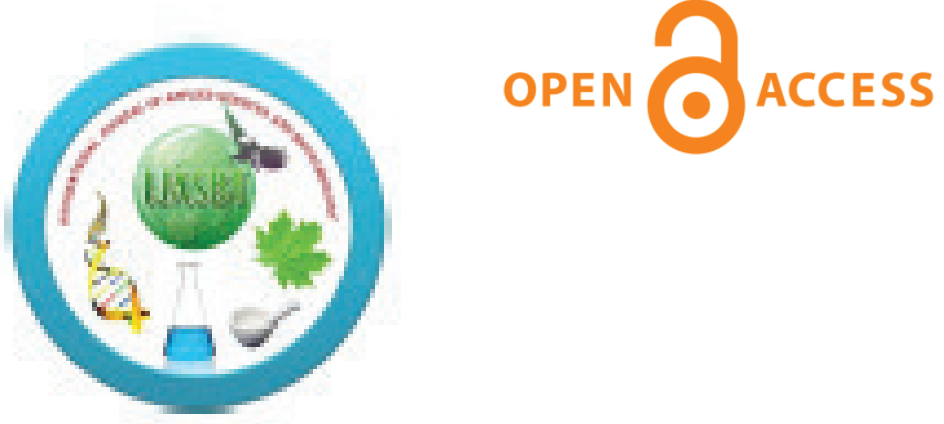

Avallable online at wwwijasht.org

International Journal of Applied Sciences and Biotechnology A Rapid Publishing Journal

\begin{tabular}{|c|c|c|}
\hline \multicolumn{2}{|c|}{ APPUED SCIENCES } & BIOUECHNOLOSY \\
\hline $\begin{array}{l}\text { Biochemistry } \\
\text { Malecular biology } \\
\text { Microbialosy } \\
\text { Cell blalogy }\end{array}$ & $\begin{array}{l}\text { Immunobiology } \\
\text { Biolinformatics } \\
\text { Novel drug delivery wstem } \\
\text { Pharmacology }\end{array}$ & $\begin{array}{l}\text { Mierablal biotechnology } \\
\text { Medical biotechnology } \\
\text { Industribl biotechnolosy } \\
\text { Enviranmental biatechnolosy }\end{array}$ \\
\hline $\begin{array}{l}\text { Cytology } \\
\text { Genetios } \\
\text { Patholony }\end{array}$ & $\begin{array}{l}\text { Neurabilology } \\
\text { Bio-physics } \\
\text { Botany }\end{array}$ & Nanatechnology \\
\hline $\begin{array}{l}\text { Medicinal chemistry } \\
\text { Polymer sdences } \\
\text { Analytical themistry } \\
\text { Natural chemistry }\end{array}$ & $\begin{array}{l}\text { Zoology } \\
\text { Allied science } \\
\text { Earth sdence }\end{array}$ & \\
\hline
\end{tabular}

If any queries or feedback, then don't hesitate to mail us at: editor.jiasbtiegmail.com

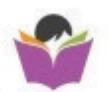




\title{
BUMPY APPLICATION OF UTILITY CODE FOR GENOMIC INVENTIONS: WITH SPECIAL REFERENCE TO EXPRESS SEQUENCE TAGS
}

\author{
M.R. Sreenivasa Murthy, K. Syamala and Harshavardhan Yadav* \\ Centre for Study and Research in IPR (CSRIPR) National University of Study and Research in Law, Ranchi (NUSRL, Ranchi) Polytechnic Campus, \\ BIT Mesra, Ranchi - 835215 (Jharkhand) \\ *Corresponding author email: harshsporty2008@gmail.com
}

\begin{abstract}
Genomics, a new bough of biotechnology responsible for gene mapping has acquired a rapid significance in the field of patents. Brisk growth of patent filing in genomic subject matter is raising serious concerns about their utility from the perspective of societal benefit. Though the genomic related patent application qualifies the criterion of invention and non-obviousness in major instances, the inventors are unable to satisfy the utility criterion. Some instances such as patent application for ESTs have no utility at all. The patent regulators constructed various tests to deal with the situation such as specificity, substantiality (real world) credibility tests etc. Hoverer, it is noteworthy that an attempt to uniform the standard of utility test for genomic inventions especially in the field of ESTs, cloning and creation of chimeras, has been made by America and Europe through specific regulations. Thus, the objective of this paper is firstly, to explain the importance of biotechnology and genomic inventions for mankind and significance of ESTs for future research. Secondly, to analyze the application of Utility code prior to the emergence of Utility code in America and Europe. Thirdly to scrutinize the Utility code in both countries and their implication on aftermath cases, and. fourthly and finally, to critically evaluate the both countries utility pathways in the light of societal benefit.
\end{abstract}

Keywords: Genetic material, Patent, Utility, Morality and Ethics

\section{Prologue}

"Genomics is the use of genome-wide analytical tools to study the effect of genes, proteins and other gene products on the biological processes of an organism” (Rothstein et al., 2006).

The science of genomics correlates genetic information with biochemical pathways and specifically with disease mechanisms (Grubb, 2010). Genomics is an inspiring development of very large longitudinal cohort study and even study of entire populations to establish repositories of biological materials ("bio-banks") for discovery and characterization of genes associated with common diseases (Khoury et. al., 2004). These "bio-banks" are an important advancement in the study of human genetics which will be identifying and characterizing numerous common genetic variants at specific loci, its combination sequence with other genes and the related chemical, physical, infectious, pharmacological and social factors. With the growth and consolidation of the biotechnology sector based upon genetic engineering that precipitated Intellectual Property into the protection of life forms and their structural and functional components. Art. 27(1) of Trade Related Aspects on Intellectual Property provides that patents shall be available and rights shall be enjoyable without discrimination as to the place of invention, the field of technology and to the place of production.

Thus, the judicial determination (e.g., Diamond $V$. Chankrabarty Case) in USA and legislation (e.g., Directive 98/44 of the EU Parliament and of the European Council, July 6, 1998 on the Legal Protection of Biotechnological Inventions, (1998) O.J.L213/13-21) in Europe treated the modification of genetic material as inventions rather than discoveries, thereby created the possibility of patenting of genetic material and enabling technologies (Blakeney, 2009). However, the latest developments after the exploration of Human Genome Project (Dutfield, 2003), shocked 
the civil society with its new developments such as gene sequencing, Express Sequence Tags (ESTs), cloning, chimeras etc., because to a large extent these inventions lacks utility be it negligible or significant (EPO - T 0939/92 (Triazoles) of 12.9.1995); EPO - T 0944/99 (Pesticidal toxins/MYCOGEN CORPORATION) of 10.12.2002) and the research seemed to cross the limitations with its crazy inventions by attempting to unfold the secrets of the nature by attempting to overwrite. Indeed, the increased number of patent applications in the field of ESTs raised concerns about the requirement of balance between commercial and societal interest. Therefore, the American and European legislators introduced guidelines i.e., "Biotechnology Directive 98/44" and Utility Examination Guidelines (2001) 66/4respectively to deal with upcoming issues relating to biotechnology patenting by heightening the utility standard by deriving Substantial, Specific \& Credibility Test.

\section{Refurbishment of utility code by Americans}

Legally speaking, a person can get patent over his invention only if his invention is New/Novel, having Inventive Step/Non-obviousness and having Industrial Application/Utility. In other words Invention that divide of these criteria can never qualify as patent. More over the modern biotechnology revolution has enabled the patent filing in genomic subject matter. However, the genomic related patent application qualifies the criterion of novelty and non-obviousness in major instances; but the inventors are unable to satisfy the utility criterion.

However, the conjoin reading of American Constitutional provision (Art I, § 8, Cl 8, empower congress 'to promote the progress of science and useful arts".) and the 35 USC § 101 of The Patent Code instituted that; certain developments that even do not lead to an industrial product may be patented in America (Chisum and Jacobs, 1992). For example, large number of patents granted in methods of doing business, and patenting of research tools, such as expression sequence tags and single nucleotide polymorphisms (USPTO Utility Examination Guidelines Federal Register, 2001).

Hence, it is a noticeable point that American legal framework allows the patentability of purely experimental inventions that cannot be made or used in an industry, or that do not produce a socalled technical effect (Dutfield, 2003).
American Supreme Court in a landmark judgment of Diamond Vs. Chakrabarty, 447 US. 303, 206 USPQ 193 (1980) held that the patentee has produced a new bacterium with markedly different characteristics from any found in nature and one having the potential for significant utility, hence a live, human-made microorganism is patentable subject matter. In Merk \& Co. v. Olin Mathieson Chemical Corp 253 F.2d 156 (1958) the court allowed purified vitamin to be patented which had no utility by relying on Judge Moore's explanation in Funk Bros. Seed Co. v. Kalo Inoculant Co., 333 U.S. 127, 130 (1948), that word "new utility" involves an "enlargement of the range of utility' as compared to nature. Further, it is interesting to note that in Brenner $V$. Manson, 383 U.S. 519, 148 USPQ 689 (1966), the court interpreted the utility condition as an essential requirement of a patent and insists that the inventor should discover at least a substantial minimal utility for his invention. The Supreme Court in this case was primarily concerned with creating an unwarranted monopoly to the detriment of the public. It was held that:

"Whatever weight is attached to the value of encouraging disclosure and of inhibiting secrecy, we believe a more compelling consideration is that a process patent in the chemical field, which has not been developed and pointed to the degree of specific utility, creates a monopoly of knowledge which should be granted only if clearly commanded by the statute. Until the process claim has been reduced to production of a product shown to be useful, the metes and bounds of that monopoly are not capable of precise delineation.

It may engross a vast, unknown, and perhaps unknowable area. Such a patent may confer power to block off whole areas of scientific development, without compensating benefit to the public. This is not to say that we mean to disparage the importance of contributions to the fund of scientific information short of the invention of something "useful," or that we are blind to the prospect that what now seems without "use" may tomorrow command the grateful attention of the public. Patent system must be related to the world of commerce rather than to the realm of philosophy".

Thus, in this case court held that the claimed chemical process lacked a utility because it could be used only to produce a compound of unknown use. 
However, In re Kirk 376 F. $2 d$ 936, 153 U.S.P.Q. 48 (CCPA 1967), the Court of Customs and Patent Appeals (herein after CCPA) expanded the substantial minimal utility rule of Manson to rule that compounds whose sole disclosed utility lay as an intermediate for the production of other compounds, which in turn have no present known use other than as objects of chemical research, did not satisfy the practical utility requirement of $\S$ 101. Further, in Joly376 F.2d 906, 153 USPQ 45 (CCPA 1967, the CCPA extended Inre Kirk utility ruleto cover process claims, holding that processes which yield chemical intermediates are also unpatentable where the intermediates are used only to create end products with no known use.

After the aforesaid judgments, a patent applicant was allowed to make an assertion of utility, which likewise should be specific, substantial, and credible (Revised Interim Utility Guidelines Training Materials).

A specific and substantial utility excludes socalled "throw-away" utilities, such as the use of a complex invention as a landfill, or the use of a transgenic mouse as snake food. In Nelson $v$ Bowler 626 F. 2d 853, 856, 206 U.S.P.Q. 881, 883 (CCPA 1980), the CCPA has interpreted "substantial utility" as "practical utility" which is a shorthand way of attributing 'real world' value to claimed subject matter. In other words, one who is skilled in the art can use a claimed discovery in a manner which provides some immediate benefit to the public"(See, Guidelines for Examination of Applications for Compliance with the Utility Requirement).

However, it is noteworthy that, the disclosure of only one utility is required, not all possible uses, and the issue of marketability does not play a role. Speculative uses in the patent application are permitted as long as one use is practical. The use of a polynucleotide simply as a probe or chromosome marker, without disclosure of a specific DNA target, would not be considered specific (Document SCP/9/5) Geneva: WIPO, 2003). The USPTO quotes In re Kirk, "We do not believe that it was the intention of the statutes to require the Patent Office, the courts, or the public to play the sort of guessing game that might be involved if an applicant could satisfy the requirements of the statutes by indicating the usefulness of a claimed compound in terms of possible use so general as to be meaningless".

Thus, it can be concluded that a utility is credible if it is believable to a person of ordinary skill in the art based on the totality of evidence and reasoning provided. If the only described utility of an EST were as a probe to search for an unknown gene that hardly would seem adequate to fulfill the criterion of being a specific, substantial and credible utility.

Finally, US passed the Biotechnology Guidelines, 2001 to allow the patenting of genomic inventions in the United States. The USPTO Guidelines are particularly relevant in areas of emerging technologies, such as gene-related technologies, where uses for new materials that have not been fully characterized are not readily apparent (Scrip Magazine, 2001).

It is explained in the Guidelines 2001 that "they do not alter the substantive requirements of 35 U.S.C. 101 and 112, nor are they designed to obviate the examiner's review of applications for compliance with all other statutory requirements for patentability. The Guidelines do not constitute substantive rulemaking and hence do not have the force and effect of law. Rejections will be based upon the substantive law, and it is these rejections which are appealable".

The Guidelines offers that an invention should be considered as having a well-established utility only "(1) if a person of ordinary skill in the art would immediately appreciate why the invention is useful based on the characteristics of the invention (e.g., properties or applications of a product or process), and (2) the utility is specific, substantial, and credible" (See, Utility Examination Guidelines, Department Of Commerce, USPTO).

In Enzo Biochem, Inc v Gen-Probe Inc296 F. 3d 1316; 63 U.S.P.Q. 2d 1609 (Fed. Cir. 2002) ("Enzo II"), the Court of Appeals for the Federal Circuit (herein after CAFC) had the opportunity to test the relevance of Guidelines issued by the USPTO concerning the written description requirement of 35 U.S.C. 112, first paragraph. The CAFC stated that it is not bound by the USPTO Guidelines but may be given judicial notice to the extent they do not conflict with the statute. It should be kept in mind that the new Utility Guidelines do not affect the afore-named provisions in 35 U.S.C. Also, they are not binding on the CAFC (Barton, 2002).

In re Dane K. Fisher and Raghunath .Lalgudi, 421 F.3d 1365, appeal from the decision of the U.S. Patent and Trademark Office, Board of Patent Appeals and Interferences ("Board") affirming the examiner's final rejection of the only pending 
claim of application entitled "Nucleic Acid Molecules and Other Molecules Associated with Plants," as non-patentable for lack of utility under 35 U.S.C. $\S 101$ and lack of enablement under 35 U.S.C. $\S 112$. Contrary to Fisher's argument that $\S$ 101 only requires an invention that is not "frivolous, injurious to the well-being, good policy, or good morals of society", the Supreme Court appeared to reject Justice Story's de minimis view of utility. The Supreme Court observed that Justice Story's definition "sheds little light on our subject," on the one hand framing the relevant inquiry as "whether the invention in question is 'frivolous and insignificant'" if narrowly read, while on the other hand "allowing the patenting of any invention not positively harmful to society" if more broadly read.

However, it is interesting note that in Fujikawa v. Wattanasin, 93 F.3d 1559, 1563 (Fed. Cir. 1996), it was ruled that a patent may not be granted to an invention unless substantial or practical utility for the invention has been discovered and disclosed. It was also observed in In re Diedrich and In re Kirk, preceding Fujikawa"that the nebulous expressions 'biological activity' or 'biological properties' appearing in the specification convey no more explicit indication of the usefulness of the compounds and how to use them than did the equally obscure expression 'useful for technical and pharmaceutical purposes' unsuccessfully relied upon by the appellant in. Thus, in addition to providing a "substantial" utility, an asserted use must also show that that claimed invention can be used to provide a well-defined and particular benefit to the public. Accordingly, the claimed ESTs are, in words of the Supreme Court, mere "objects of use-testing," to wit, objects upon which scientific research could be performed with no assurance that anything useful will be discovered in the end (Raghunath Lalgudi Case).

The Brenner court already in 1996 stated that "the Congress is not intended to grant patent on a chemical compound whose sole 'utility' consists of its potential role as an object of use-testing, a different set of rules was meant to apply to the process which yielded the un-patentable product."

Thus, applying the same logic, it can be asserted that the claimed ESTs, which do not correlate to an underlying gene of known function, fail to meet the standard for utility intended by Congress.

II. Refurbishment of utility code by Europeans:
Under the European Patent Convention (EPC) Art. 57 provides in a quite straightforward manner that an invention shall be considered as susceptible of industrial application if it can be made or used in any kind of industry, including agriculture (Minssen and Nilsson, 2012). Rule 27(1) (f) EPC prescribes that the description should "indicate explicitly, when it is not obvious from the description or nature of the invention, the way in which the invention is capable of exploitation in industry."

Biotechnological inventions are quite often concerned with substances found in nature e.g. a protein, a DNA sequence, etc where the structure and function of the substance capable of being manufactured requires to be susceptible to industrial applicability standard (Examination Guidelines for Patent Applications relating to Biotechnological Inventions in the IP Office July 2012). If a function is well known to be essential for human health, then the identification of the substance having this function will immediately suggest a practical application in case of a disease or condition caused by a deficiency. In such cases, an adequate description will ensure in accordance with the requirements of Article 57 EPC that "the inventioncan be made or used in industry" $(T$ 0870/04_(BDP1 Phosphatase/MAX-PLANCK) EPO ). The requirement is that the industrial application of a sequence or a partial sequence of a gene must be disclosed in the patent application would appear to stem from the concerns expressed about the many patent applications that were filed for gene elements of totally unknown biological function (See,Arts 54, 56, 57 of EPC). Even if the language of Article 57 EPC were interpreted as meaning that the "making" referred to had to be in industry, there was nothing to indicate that the word "industry" had a particular or narrow meaning. In the context of this broad nature of industry, the "could be made in industry" test was more than enough for any invention. However, it is significant to note here that this interpretation of Rule 23(b) and (e) EPC must be made in conformity with Article 164(2) EPC and further Rule 27(1) (f) EPC imposed an additional practical requirement beyond Art.57 EPC.

In Appetite suppressant EPO - T0144/83 case, it has been observed that the notion of "industry" has to be interpreted broadly to include all manufacturing, extracting and processing activities of enterprises that are carried out continuously, independently and for financial (commercial) gains (EPO - T 0870/04 (BDP1 
Phosphatase/MAX-PLANCK). The requirement of Article 57 EPC that the invention"can be made or used" in at least one field of industrial activity emphasizes that a "practical" application of the invention has to be disclosed. Merely because a substance could be produced in some ways does not necessarily mean that this requirement is fulfilled, unless there is also some profitable use for which the substance can be employed (Appetite suppressant Case at 301).

In Europe, the specific protection of biotechnological inventions is regulated by Directive $98 / 44$ on the Legal Protection of Biotechnological Inventions, ("Biotechnology Directive"). The Recital 2 of the Directive notes the importance of patents in the field of biotechnology. The Directive states that Member States shall protect biotechnological inventions, and that human genetic material is patentable. Paragraph 1 of Art.3 of the Directive provides: "For the purposes of this Directive, inventions which are new, involve an inventive step and which are susceptible of industrial application shall be patentable even if they concern a product consisting of or containing biological material or a process by means of which biological materialis produced, processed or used."

Thus genomic inventions such as genes and gene fragments that meet the standard patentability criteria of novelty, inventiveness and industrial applicability in principle are patentable subjectmatter (Crespi, 1999). The second paragraph of Art.3 of the Directive clarifies that "Biological material which is isolated from its natural environment or produced by means of a technical process may be the subject of an invention even if it previously occurred in nature". Article 5 of the Directive addresses more specifically the patenting of sequences or partial sequences of genes.

Finally, the third paragraph of Art.5 of the Directive expands the criterion of industrial applicability in comparison to Art.3 which mentions the general patentability criteria of novelty, inventiveness and industrial applicability. According to the third section of Art.5 a new and specific requirement is created for the patentability of a sequence or a partial sequence of a gene, namely the requirement of disclosure of the industrial application of the nucleotide sequence in the patent application. This requirement does not apply to sequences or partial sequences of proteins (Aerts, 2004).
The provision of Art.5 (3) of the Directive is found in the same words in rule 23e (3) of the Implementing Regulations to the EPC. The provision of rule $23 \mathrm{e}(3)$ EPC distinguishes genomic inventions from other inventions, for which it is sufficient if the invention "can be made or used" is sufficient to fulfill the requirement of industrial applicability under the EPC. The other relevant legal background that had to be taken into account was the EU Directive 98/44/EC on the legal protection of biotechnological inventions and its adoption by the EPO. Recitals (22) to (25), (28) and (34) all emphasized and made clear that the legislative intention was not to change relevant basic law, inter alia the provisions on susceptibility to industrial application.

There was no basis in the law for requiring a function of a sequence to be "specific" or for having any form of concern about the "vagueness" of a sequence's function. The examining division adopted the position that what was not "specific" was vague and, ipso facto, not enough for patentability. This view ignored the law and went against basic common sense and fundamental fairness. In fact, functions upon which industrial activity could be supported were often general and not "specific" in the way the examining division meant (EPO - T 0898/05 (Hematopoietic receptor/ZYMOGENETICS, 2006).

Indeed, Recitals 23 and 24 of the Directive provide further explanation: "Whereas a mere DNA sequence without indication of a function does not contain any technical information and is therefore not a patentable invention; Whereas, in order to comply with the industrial application criterion it is necessary in cases where a sequence or partial sequence of a gene is used to produce a protein or part of a protein, to specify which protein or part of a protein is produced or what function it performs".

In EPO - T 1452/06 (Serine protease/BAYER) of 10.05.2007, the question raised as to whether, in the absence of the experimental evidence, the application provides enough support for the assumption that it has industrial application to fulfill Art.57 requirement. It has been argued that, although no experimental evidence has been provided for serine protease activity of a polypeptide of sequence SEQ ID NO: 24, the structural identification of this polypeptide as being a member of a family of proteins with known industrial interest, namely the family of serine proteases and the subgroup of type II 
membrane serine proteases, provides enough support for industrial applicability. This indication must have "a sound and concrete technical basis", as a "speculative indication of possible objectives that might or might not be achievable by carrying out further research with the tool as described is not sufficient for fulfillment of the requirement of industrial applicability". Basing on the "immediate concrete benefit" test the appeal has been dismissed.

Eli Lilly v Human Genome Sciences [2011] UKSC 51, was the first case to be heard before the UK Courts in genomics which rejected the patent application on the grounds that it lacked industrial applicability basing on the European Board of Appeal in T 0018/09 where in Lord Neuberger who referred to as 'the essence of the Board's approach in relation to the requirements of Article 57 in relation to biological material' on nine points.

However, the decisionin, HGS v. Eli-Lilly gives us guidance on how to deal with applications that apparently lack industrial application, and therefore these principles should be taken into consideration when assessing an invention for industrial application. In $T$ 0641/05 Pharmacial GPCR-like receptor, the EPO Technical Board of Appeal made a distinction between a case where a substance has been elucidated or is known in the art, and a case where a substance is identified and possibly characterized, but its function is not known: industrial application can generally be acknowledged for the former and not for the latter. A claimed invention must have such a sound and concrete technical basis that the skilled person can recognize that its contribution to the art could lead to practical exploitation in industry, i.e. to a concrete benefit, which is immediately derivable directly from the description, if it is not already obvious from the nature of the invention or from the background art. It is necessary to disclose in definite technical terms the purpose of the invention and how it can be used in industrial practice to solve a given technical problem, this being the actual concrete benefit or advantage of exploiting the invention."

In Zymogenetics/ Haematopoietic receptor (not reported) ( $T$ 0898/05), the lack of any industrial application for one aspect of an invention can have implications for other aspects of that invention. For example, if the one aspect of the invention is a receptor, the absence of any industrial application for the receptor would mean that an agonist to the receptor would also not be capable of industrial application. Similarly, a method of identifying agonists to the receptor would not be industrial applicable. On the other hand, if the specification established, for example by in vivo or in vitro data, that the receptor had some relevance to e.g. the treatment of obesity, the receptor, agonists and method of identifying agonists would all be capable of industrial application. Whilst a crystalline form of a protein may be novel it must have a specific, substantial and credible industrial application. The EPO, USPTO and JPO issued their trilateral report on protein $3 \mathrm{D}$ structure and related claims at the end of 2002. The practice of the Intellectual Property Office in this area is largely consistent with the conclusions of this trilateral study.

The legislative competence of the above implication may be flaw since a rule in the Implementing Regulations to the EPC cannot take precedence over an Article of the EPC (See, Art.164 (2) EPC). According to European patent law patentability is governed both by an intergovernmental treaty (the EPC) and by Community Law i.e., the Biotechnology Directive. Although r.23e(3) of EPC cannot take precedence over Art.57 EPC still it does not constitute substantive law and is binding as to the result to be achieved upon the Member States according to Art.249 EC Treaty.

\section{Winding Up}

The history of science and technology is incomplete without reference to biotechnology and genomics, which refers to the mapping, sequencing and analysis of the full set of genes of different organisms or species. Genomics is a rapidly emerging area of research which in the future years will revolutionize the understanding of biology (Chawla, 2002). As one might expect, the human genome has always been the most interesting for governments and foundations, as well as for companies seeking to identify commercial applications from genomics (Dutfield, 2003). The excavation of secrets behind nature created ample commercial potential after human genome project. The increased number of patent applications in the field of ESTs raised concerns about the requirement of balance between commercial and societal interest.

The arguments against patenting of gene in Diamond vsChakrabarty, initiated the further swing of row when it came to ESTs patenting as road block for future research. Though the utility 
standard among the three basic patentability criterions was applied liberally in olden days, after Brenner vs Manson, it has been considered as an essential requirement and declaring at least one substantial minimal utility has been considered important. The later judgments of American and European courts show the bumpy application of utility code for genomic inventions until the utility code haven't emerged in both countries as a process of standardization. The raising concern of society on the grounds of ethics and morality is the root cause for the oscillated application of utility code for genomic inventions. In some instances, the description of utility for some inventions is in such way that the end product has no known use in the present day context (In re Kirk Case). The utility code of both countries though tried to put a hold on the strong wave of ESTs patenting with its stratagem imposition of need of proof of practical utility and credibility yet there is flow of patent applications for ESTs. The American Supreme Court in the recent judgment laid down that patent cannot be granted for inventions which are mere "objects of use-testing", which has no assurance of raising anything useful end product (In re Dane K. Fisher and Raghunath . Lalgudi case). In the same way, European courts are also restricting the patenting of ESTs by applying the rule of concrete benefit, which is immediately derivable directly from the description (Eli Lilly Case).

A claimed invention must have such a sound and concrete technical basis that the skilled person can recognize that its contribution to the art could lead to practical exploitation in industry, i.e. to a concrete benefit, which is immediately derivable directly from the description, if it is not already obvious from the nature of the invention or from the background art. It is necessary to disclose in definite technical terms the purpose of the invention and how it can be used in industrial practice to solve a given technical problem, this being the actual concrete benefit or advantage of exploiting the invention."

From this it is evident that the Dedicated Biotechnology Firms are striving hard to overcome the regulatory hurdles to commercialize their inventions in various invented trickled methods in the interest of minority society. The substantial part of the society is clearly diverging from the above approach and raising their concerns related to morality and ethics. The need for balance is at the threshold of the regulators on whose shoulders the welfare of the larger mass of the society is resting. The jurisprudence behind granting monopoly rights for inventions should be uphold with a caution test of societal benefit linked with a standardization of utility code for emerging genomic research.

\section{Reference}

Aerts RJ (2004) The Industrial Applicability and Utility Requirements for The Patenting of Genomic Inventions: A Comparision Between EU and US Law. EIPR 26(8):349-360.

Article 54, 56, 57 of EPC Available at: http://www.epo.org/law-practice/legaltexts/html/epc/1973/e/ma1.html

Barton JH (2002) United States Law of Genomic and Postgenomic Patents. International Review of Industrial Property and Copyright Law 33(7): 782.

Blakeney ML (2009) Intellectual Property Rights and Food Security. CAB International, Wallingford, Oxford.

Chawla HS (2002) Introduction to Plant Biotechnology. Oxford \& IBH Publishing Co. Pvt. Ltd., New Delhi. $2^{\text {nd }} E d$.

Chisum DS and Jacobs MA (1992), Understanding Intellectual Property Law. Legal Text Series 2-50, Maththew Bender, New York .

Crespi RS (1999) The Biotechnology Patent Directive is Approved at Last. Trends in Biotechnology 140: 17.

Directive 98/44 of the EU Parliament and of the European Council, July 6, 1998 on the Legal Protection of Biotechnological Inventions, (1998) O.J.L213/13-21. Available at: http://eur-lex.europa.eu/LexUriServ/Lex

Dutfield G (2003) Intellectual Property Rights and the Life Science Industries: A Twentieth Century History. Ashgate Pub. Ltd., England,

Examination Guidelines for Patent Applications relating to Biotechnological Inventions in the Intellectual Property Office July 2012 Concept House Cardiff Road Newport South Wales NP10 8QQ, Available at http://www.ipo.gov.uk/biotech.pdf.

Grubb PW. (2010) Patents for Chemicals, Pharmaceuticals and Biotechnology: Fundamentals of Global Law, Practice and Strategy. 265 ( $4^{\text {th }}$ ed. Oxford Univ. Pres).

Guidelines for Examination of Applications for Compliance with the Utility Requirement. Available at http://www.uspto.gov/web/offices/pac/mpep/s2107.html.

International Bureau of WIPO (2003) 'Industrial Applicability' and 'Utility' Requirements: Commonalities and Differences 10 (Document SCP/9/5) Geneva: World Intellectual Property Organization

Khoury MJ et. al. (2004) The Emergence of Epidemology in the Genomics Age. Int. J. Epidemiol 33: 936.

Revised Interim Utility Guidelines Training Materials. Available at: http://www.uspto.gov/web/menu/utility.pdf 
MR Sreenivasa Murthy et al. (2013) Int J Appl Sci Biotechnol, Vol 1(4): 189-196

Rothstein MA and Boehl HF (2006) Genomics and Public Health: Legal and Socio-Ethical Perspectives: Privacy Issues In Public Health Genomics. 150 (BARTHA MARIA KNOPPERS eds. MartinusNijhoff, Leiden / Boston).

Scrip Magazine (Jan.2001) US Issues Final Gene Patent Guidelines, 16.

The Recitals of Directive 98/44 on the Legal Protection of Biotechnological Inventions. Available at: http://eurlex.europa.eu/LexUriServ/LexUriServ.do?uri=CELEX:31 998L0044:en:NOT

Timo Minssen \& David Nilsson (2012) The Industrial Application Requirement for Biotech Inventions in Light of Recent EPO \& UK Case Law: A Plausible Approach or A Mere "Hunting License"? E.I.P.R 34(10).

US Patent and Trademark Office, Revised Utility Guidelines Training Material 5 Available at: www.uspto.gov/web/menu/utility.pdf

US Patent and Trademark Office, Utility Examination Guidelines (2001) 66/4 Federal Register, 1098.

USPTO Utility Examination Guidelines Federal Register, Vol. 66 No. 4 January 5, 2001.

Utility Examination Guidelines, Department Of Commerce, Uspto, Available at http://www.uspto.gov/web/offices/com/sol/og/2009/week 52/TOCCN/item-177.htm

\section{Case Laws}

Appetite suppressant EPO - T0144/83
Brenner V. Manson, 383 U.S. 519, 148 USPQ 689 (1966),

Diamond Vs. Chakrabarty, 447 US. 303, 206 USPQ 193 (1980)

Eli Lilly v Human Genome Sciences[2011] UKSC 51, .

Enzo Biochem, Inc $v$ Gen-Probe Inc296 F. 3d 1316; 63 U.S.P.Q. $2 d 1609$ (Fed. Cir. 2002)

EPO - $\quad \mathrm{T} \quad 0898 / 05 \quad$ (Hematopoietic receptor/ZYMOGENETICS, 2006

EPO - T 1452/06 (Serine protease/BAYER) of 10.05.2007,

Fujikawa v. Wattanasin, 93 F.3d 1559, 1563 (Fed. Cir. 1996),

Funk Bros. Seed Co. v. Kalo Inoculant Co., 333 U.S. 127, 130 (1948)

In re Dane K. Fisher and Raghunath.Lalgudi, 421 F.3d 1365

In re Kirk 376 F. 2d 936, 153 U.S.P.Q. 48 (CCPA 1967),

Joly376 F.2d 906, 153 USPQ 45 (CCPA 1967,

Merk\& Co. v. Olin Mathieson Chemical Corp 253 F.2d 156 (1958)

Nelson v Bowler 626 F. 2d 853, 856, 206 U.S.P.Q. 881, 883 (CCPA 1980),

T 0641/05 Pharmacial GPCR-like receptor,Zymogenetics/ Haematopoietic receptor (not reported) (T 0898/05),

T 0870/04_(BDP1 Phosphatase/MAX-PLANCK) EPO 